\section{Human Heredity}

\title{
Dr. Richard Spielman
}

Dr. Richard Spielman, the Butterworth Professor of Genetics in the School of Medicine of the University of Pennsylvania, passed away on April 25. He was 63 years old.

Dr. Spielman, who joined the Penn faculty in 1974, was a world-renowned expert in the fields of human genetics and genomics. His seminal work with Dr. Warren Ewens of the Biology Department, on family-based genetic associations studies, the Transmission Disequilibrium Test (TDT), has been cited more than 2,400 times to date and has had a major impact on the field. His more recent studies with Dr. Vivian Cheung of the Children's Hospital of Philadelphia, were the first to investigate the genetics of natural variation of gene expression in humans.

Dr. Spielman was committed to teaching both graduate students and medical students. He was the founding chair of the Genomics and Computational Biology Graduate Group, which has become the model for similar programs elsewhere. He also served on multiple academic committees at the School of Medicine over the years.

Dr. Spielman received his AB from Harvard College cum laude in 1967, and both master's and $\mathrm{PhD}$ degrees in human genetics from the University of Michigan. After completing his postdoctoral training at Michigan in 1974, he joined what was then the Department of Human Genetics at Penn. He served on the editorial boards of several prominent journals, including the Journal of Clinical Investigation, the American Journal of Human Genetics, and Genome Research. He was a member of multiple NIH study sections, and served on the program committee of the American Society of Human Genetics.

Dr. Spielman is survived by his wife, Vivian; and daughter, Anita.

A memorial service is planned for the fall in Philadelphia.

Contributions may be made to the Richard Spielman Memorial Fund

Department of Genetics, 475 CRB, 415 Curie Blvd.

Philadelphia, PA 19104-6145.

This originally appeared in Almanac, Volume 55, No. 34, May 26, 2009, and is republished with permission. 